\title{
Ojämlikhet och polarisering i detaljhandeln 1990-2015
}

\author{
Stefan Carlén \& Paulina de los Reyes
}

\section{Inledning}

Den ökade ojämlikheten i arbetslivet är nära kopplad till den kraftiga ökningen av mer osäkra och flexibla anställningsförhållanden. I Sverige har denna utveckling, ofta kallad prekarisering, accelererat sedan 1990-talet. I många andra kapitalistiska länder inleddes utvecklingen tidigare, redan under 1970-talet. I ett globalt perspektiv har reglerade arbetsvillkor och stabila anställningar snarast varit ett undantag.

I det här kapitlet kommer vi att titta närmare på den svenska utvecklingen av ojämlikhet $\mathrm{i}$ arbetslivet och vilken roll osäkra anställningsformer har spelat i denna. Fokus ligger på detaljhandeln, som är en av de största privata branscherna inom svenskt näringsliv. Det finns flera skäl till att detaljhandeln är viktig att studera. Ett skäl är att det är den privata bransch där antalet tillfälliga anställningar och deltidsanställningar är störst (LO 2017). Ett annat är att handeln har vuxit och fått större betydelse i denna fas av kapitalismen. Handelns stora transnationella företag har de senaste decennierna spelat en avgörande roll i ett större ekonomiskt skifte som påverkat kapitalismens funktion, organisering och sociala maktrelationer. Den industriella produktionen har gått från att vara producentdriven till att vara detaljhandelsdriven (Chan 2011; Coulter 2014). Skiftet kan illustreras med Wal-Mart, som i kraft av sin starka maktposition inom detaljhandeln kunde sätta press på industriföretag, bestämma vem som skulle få leverera samt till vilken kostnad. Detsamma gäller de flesta dominerande globala detaljhandelsföretag. 
På så vis spelar handelskapitalet en betydande roll i polariseringen av löner och arbetsvillkor globalt och nationellt - inte bara inom handeln, utan dess nya dominans har påverkat även andra sektorer i ekonomin (Lichtenstein 2006).

Vi kommer att kartlägga och analysera utvecklingen inom den svenska detaljhandeln mellan 1990 och 2015 och diskutera såväl orsakerna till den ökade ojämlikheten som de konsekvenser för arbetsliv och hälsa som den fört med sig. Vi förväntar oss att utvecklingen har påverkat olika grupper i samhället olika mycket, och det kommer vi att belysa med statistik. Vi är väl medvetna om att de siffror vi använder endast ger en grov approximation till kategoriseringar som rör klass, kön eller ras och etnicitet. Den socioekonomiska indelningen mellan arbetare och tjänstemän utgår från en taxonomisk förståelse av klass och problematiserar inte relationer mellan klasser. I brist på andra alternativ använder vi kategorin "utlandsfödda" för att illustrera den utsortering som drabbar anställda som har migrerat till Sverige, men vi vet att även barn till migranter är föremål för rasistiskt särskiljande i arbetsmarknadssituationer. Risken är därför stor att vi underskattar den ojämlikhet som skapas i och genom rasifieringsprocesser i arbetslivet. Trots dessa förbehåll hoppas vi att vårt bidrag kan leda till en bättre förståelse av ojämlikhetens olika dimensioner under den undersökta perioden.

Kapitlet inleds med en presentation av generella förändringar i anställningsformer under perioden 1990-2015. Vi kopplar den kraftiga ökningen av tidsbegränsade anställningar till konjunkturväxlingar och förändrade regelverk.

I kapitlets andra avsnitt belyser vi polariseringen mellan arbetare och tjänstemän och mellan kvinnor och män inom detaljhandeln utifrån anställningsform.

Det tredje avsnittet handlar om butiksanställdas inkomster och betydelsen av osäkra anställningskontrakt för lönespridningen inom sektorn. Effekterna av tidsbegränsade anställningar varierar med strukturella faktorer som de anställdas kön, klass och etniska bakgrund. Vi analyserar dessa skillnader utifrån data från 2015 och på basis av befintliga kategorier i statistiken (socioekonomisk indelning, kön och födelseland).

I kapitlets näst sista avsnitt ger vi en inblick i hur tidsbegränsade anställningar påverkar arbetsmiljön och de anställdas hälsa på arbets- 
platsnivå. För att belysa situationen inom Handels utgår vi från två enkäter som riktades till ett slumpmässigt urval medlemmar 2015 och till alla skyddsombud 2016.

Vi avslutar kapitlet med en kort summering av våra resultat och en reflexion om vad de säger om relationen mellan tidsbegränsade anställningar och ojämlikhetsutvecklingen $i$ arbetslivet.

\section{Bakgrund och utgångspunkter}

Ur ett längre ekonomisk-historiskt perspektiv är ökningen av osäkra jobb inget unikt för Sverige. Även under tidigare faser av kapitalismen har det funnits perioder då oregelbundna och otrygga anställningar har varit vanligt förekommande. Exempelvis var det vanligt i början av 1900-talet att anställningar inom jordbruket, industrin och tjänstesektorer var otrygga och tidsbegränsade. Under efterkrigstiden - i samband med att fackföreningarna växte, sociala åtaganden ökade och välfärdsstaten byggdes ut - kom dock arbetslivet att förknippas med ökad anställningstrygghet. Det skedde i så stor utsträckning att arbeten som inte kan beskrivas som fasta anställningar på heltid fortfarande kallas "icke-standardiserade anställningar". Merparten av de gifta kvinnorna var vid denna tid hemarbetande eller arbetade deltid. Invandrade kvinnor och män arbetade oftast heltid och rekryterades till specifika branscher. Trots dessa skillnader var normen - åtminstone den manliga normen för inrikes födda arbetare - en fast anställning på heltid.

Men efter 1970-talets ekonomiska kriser skedde en större förändring. I sin kända studie över prekariatets uppkomst i USA visar Arne Kalleberg att 1970-talet blev en historisk vändpunkt och markerade ett slut för efterkrigstidens ökande trygghet för arbetare. Prekariatet växte bland alla grupper men bestod främst av kvinnor, icke-vita medborgare och nyinflyttade invandrare. När Kalleberg skrev detta, trettio år efter vändpunkten, var fortfarande afroamerikaner, latinamerikaner och immigranter koncentrerade till de mest osäkra och lågkvalificerade arbetena.

Kalleberg ger många förklaringar till förändringen, som industrins minskade betydelse, tjänstesektorns framväxt och fler tvåförsörjarhushåll. Men särskilt fanns förklaringarna i avregleringar och försämrade 
institutionella skydd för arbetare: urholkade minimilöner, försvagade fackföreningar och ökad marknadsmakt hos företagen (Kalleberg 2011).

Förändrade maktförhållanden lyfts också fram i antologin Precarious employment in perspective. Old and new challenges in working conditions in Sweden (Thörnquist \& Engstrand 2011), som belyser prekariseringsprocesser i ett svenskt sammanhang. Författarna visar den historiska kontinuiteten mellan den etniska och könsmässiga segregeringen på arbetsmarknaden under efterkrigstiden och en ökad prekarisering i nyliberalismens spår. Arbetsorganisatoriska förändringar har inte enbart att göra med ekonomiska incitament, institutionellt regelverk och förändrade styrkeförhållanden mellan arbete och kapital, menar författarna. Förändringarna ska också ses i ljuset av den strukturella ojämlikhet som historiskt har skilt mellan olika sorters arbetskraft och gett dem olika möjligheter att påverka den fackliga agendan. Uppfattningen om en "ideal" arbetskraft utifrån klass, kön, ålder och födelseland är därför starkt kopplad till en norm som naturaliserar ojämlikheten i arbetslivet.

Debatten om hur tendenserna mot en ökad prekarisering ska tolkas är omfattande, och det finns skilda uppfattningar om dess orsaker och långsiktiga konsekvenser för ojämlikheten i arbetslivet. Medan vissa författare fokuserar på bristande regelverk eller effekter av en heterogen arbetskraft, lyfter andra fram följderna av en kapitalackumulationsmodell som maximerar sina vinster genom att minimera kostnaderna för arbetskraften (Neilson \& Rossiter 2008; Standing 2011; Virno 2011). Instabila arbetsvillkor innebär inte bara försämrade försörjningsmöjligheter för individen utan också en splittrad arbetsgemenskap och självcensur bland de anställda.

Oavsett ståndpunkt har forskare sett prekariteten som ett generellt samhällsproblem. Att vissa grupper drabbas hårdare och att utsattheten sammanfaller också med en underordnad position i samhället. Det finns dock en skiljelinje mellan studier som använder dessa underordnade positioner som en förklaring till prekära arbetsvillkor och studier som i stället riktar sökarljuset mot processer som gör vissa människor mer utsatta än andra. Begrepp som "rasifiering" och "feminisering" problematiserar de utsorteringsmekanismer som skapar och vidmakthåller ojämlikheten i arbetslivet utifrån föreställningar om ett essentiellt (och oföränderligt) annanskap. 
Under de senaste åren har intersektionella perspektiv på arbetslivet lyft fram hur särskiljande processer konstruerar varandra och bidrar till att normalisera ojämlikheten och öka utsattheten för vissa grupper på arbetsmarknaden (se t.ex. Mulinari \& Selberg 2011; Sjöstedt Landén m.fl. 2015). För att kunna analysera hur dessa processer är kopplade till ökad ojämlikhet i ett svenskt sammanhang behövs empiriska studier som belyser specifika branscher och utvecklingen över tid.

\section{Den svenska arbetsmarknaden och jobbens kvalitet 1990-2015}

Under 1970- och 1980-talen rådde på den svenska arbetsmarknaden hög sysselsättning och låg arbetslöshet $\mathrm{i}$ jämförelse med exempelvis i USA och Västeuropa. ${ }^{1}$ I slutet av 1980-talet hade vi i det närmaste full sysselsättning och brist på arbetskraft. De anställdas position på arbetsmarknaden var därmed stark: när företagen hade svårt att få tag på arbetskraft måste de erbjuda tryggare anställningsvillkor vid rekryteringar. Antalet fast anställda ökade medan antalet tidsbegränsat anställda minskade kraftigt. Första kvartalet 1990 var knappt 3,7 miljoner personer fast anställda, och endast 381 ooo hade en tidsbegränsad anställning, i huvudsak vikariat och provanställningar, det vill säga övergående former av tidsbegränsade anställningar.

Tjugofem år senare, 2015, var antalet fast anställda - trots en befolkningstillväxt på 1,3 miljoner - lägre än 1990 och uppgick till knappt 3,5 miljoner, medan antalet tidsbegränsat anställda hade ökat till drygt 636000 (SCB 2018). Vad var det som hade hänt under denna period? Hur hade det påverkat jämlikheten i arbetslivet, och vilka förklaringar kan vi hitta till denna utveckling?

En delförklaring är vissa ändringar i lagstiftningen, vilka i sin tur avspeglade förändrade styrkeförhållanden mellan arbete och kapital. Tidsbegränsade anställningar regleras sedan 1974 i lagen om anställningsskydd (LAS). Innan LAS tillkom fanns inga generella lagliga inskränkningar för att visstidsanställa, utan det reglerades i kollektivavtal. LAS 1974 var framför allt inriktat på att stärka skyddet för tillsvidareanställda, men lagen innebar även juridiska möjligheter att anställa personer för 
viss tid, viss säsong eller visst arbete. Bortsett från en smärre förändring 1982 var regelverket i stort sett intakt fram till 1990-talet.

Efter 1990 utökades möjligheterna till mer instabila anställningsformer. Under den borgerliga regeringen 1991-1994 genomfördes flera förändringar. En sådan var den lag om privat arbetsförmedling och uthyrning av arbetskraft som började gälla 1 januari 1992. Det blev tillåtet för bemanningsföretag att hyra ut arbetskraft, något som ytterligare underlättades 1993. Beträffande tidsbegränsade anställningar gjordes flera förändringar i LAS 1994. Bland annat förlängdes den längsta tilllåtna tiden i provanställning från sex till tolv månader, och kravet på tillfällighet slopades för anställning vid arbetstoppar. Denna förändring gav betydligt större möjligheter för företag att visstidsanställa.

Efter regeringsskiftet återställde den socialdemokratiska regeringen lagstiftningen, som i princip fick samma utformning som före förändringen 1994. Men redan 1 januari 1997 införde regeringen en ny anställningsform: överenskommen visstidsanställning. Den gav företagare rätt att anställa personer på tidsbegränsade kontrakt utan några särskilda skäl. Det fanns vissa restriktioner: anställningen fick omfatta sammanlagt tolv månader under en treårsperiod och anställningskontrakten skulle vara på minst en månad. Vidare fick en företagare ha högst fem anställda med överenskommen visstidsanställning samtidigt.

Tio år senare, 2007, införde den nytillträdda alliansregeringen allmän visstidsanställning, vilket ytterligare ökade möjligheterna att anställa på tidsbegränsade kontrakt.

Sammanfattningsvis kan man säga att lagstiftningen under hela perioden som vi undersöker rörde sig i riktning mot underlättande av visstidsanställningar. Vilka konsekvenser har det haft? Figur 2.1 visar fördelningen mellan fasta och tidsbegränsade anställningar under perioden 1987-2015.

I figur 2.1 ser vi att antalet fasta jobb ökade medan antalet tidsbegränsade sjönk under det senare 1980-talets högkonjunktur. ${ }^{2}$ Det är förväntat med tanke på att de anställdas position stärktes och det i praktiken rådde näst intill full sysselsättning. Den goda konjunkturen höll i sig men började långsamt mattas av under sista kvartalet 1990. Därefter drabbades Sverige av 1990-talskrisen, en internationell lågkonjunktur som övergick i en svår svensk kris. Totalt försvann drygt 600 ooo jobb 


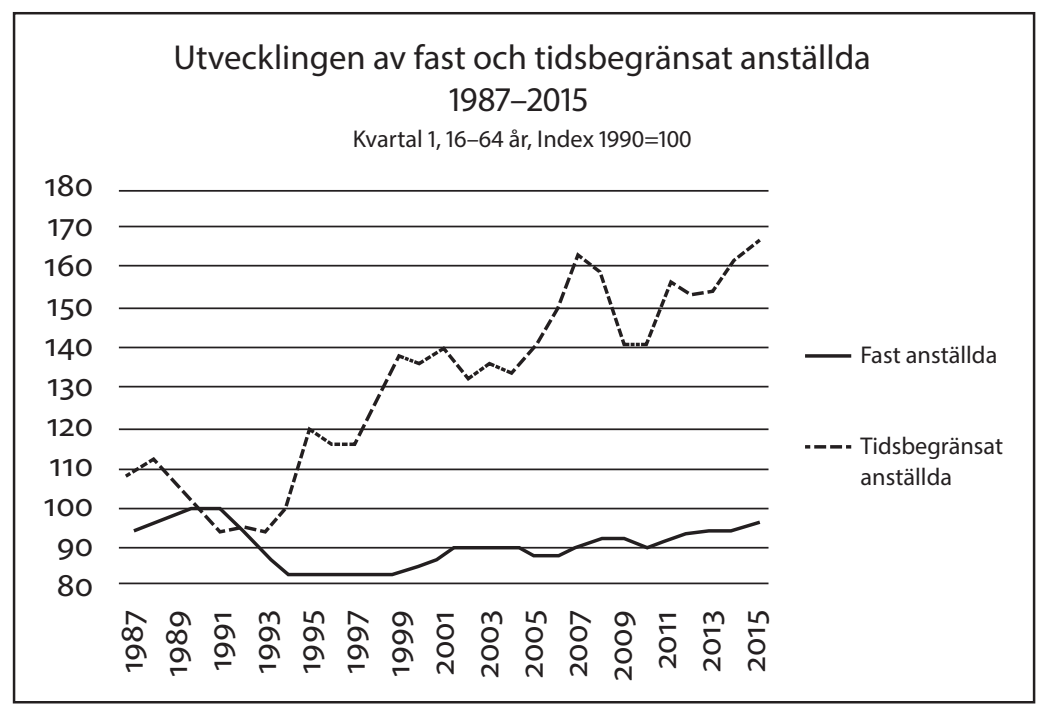

Figur 2.1. Källa: SCB 2018.

och sysselsättningsgraden sjönk från sin topp på 84 procent ner till 71,5 procent (SCB 2018). Denna kris förändrade den svenska arbetsmarknaden på ett sätt som fortsatt haft stor påverkan på arbetslivet.

Mellan 1991 och 1993 minskade både fasta och tidsbegränsade anställningar. Men 1994 fortsatte de fasta anställningarna att minska medan de tidsbegränsade istället ökade. Det sammanföll med den arbetsrättsliga förändring som infördes 1 januari 1994 och trenden fortsatte även under 1995. Därefter skedde en minskning mellan 1995 och 1997, vilket sammanföll med återställningen av LAS. Den kraftiga ökningen efter 1997 sammanföll i sin tur med den socialdemokratiska regeringens vändning och införandet av överenskommen visstid.

Under det svaga konjunkturläge som följde efter it-kraschen 2001 fram till 2005 var antalet tidsbegränsade anställningar relativt konstant. I samband med att konjunkturen vände efter 2005 ökade de tidsbegränsade anställningarna. De nådde sin kulmen i toppen av högkonjunkturen under 2007 och 2008. Därefter kom finanskrisen hösten 2008 och höll i sig under 2009 och 2010. Då minskade de tidsbegränsade anställningarna kraftigt. 
En intressant iakttagelse är att visstidsanställningarna tycks ha följt ett annat konjunkturmönster än tidigare. I högkonjunkturen i slutet av 1980-talet minskade de, men i högkonjunkturen före finanskrisen ökade de kraftigt. I den efterföljande lågkonjunkturen efter finanskrisen minskade de. I den förbättrade konjunktur som följde har de dock ökat igen. Det verkar som att visstidsanställningar blev en konjunkturregulator mot slutet av den period vi undersöker.

Den allmänna visstidsanställning som infördes 1 juli 2007 gav arbetsgivare större möjligheter att visstidsanställa utan motivering i 24 månader under en femårsperiod. Korta timanställningar utan särskild motivering eller objektiva skäl blev möjliga. Den tidigare formen överenskommen visstid hade krävt minst en månads kontrakt och maximalt fem personer anställda på sådana kontrakt per arbetsplats. Det går inte att i den övergripande statistiken se några tydliga effekter av denna förändring. En möjlig förklaring är att många visstidsanställda sades upp i samband med finanskrisen 2008. En annan förklaring kan vara att gränsen för hur många tillfälligt anställda en arbetsplats kunde ha för att fungera redan var uppnådd. Men som vi ska se längre fram påverkade lagstiftningen vilken typ av tidsbegränsad anställning som erbjöds samt innehållet i anställningen.

Om det vi kallar "jobbens kvalitet" kan man i internationell forskning använda begreppen good jobs och bad jobs (Kalleberg 2011; Ton 2014). Vad som är bra och dåliga jobb är relativt och kontextberoende. Jobb är alltid inbäddade i formella och informella institutionella sammanhang, och de påverkas av lagar, kollektivavtal, uppfattningar, normer och regler. De vanligaste kriterierna inom samhällsvetenskaplig arbetslivsforskning för om något är ett bra jobb eller inte är ekonomisk ersättning (lön, förmåner, avsättningar till pension och försäkringar med mera), arbetstider, anställningstrygghet, delaktighet och medbestämmande, makt och kontroll över arbetets innehåll och utförande, makt över arbetstider och schemaläggning, karriärmöjligheter samt möjligheter att kombinera arbetsliv med familjeliv. Många uppfattar goda anställningsvillkor som avsaknaden av ojämlikhet, diskriminering och trakasserier på arbetsplatsen (se vidare Behtoui m.fl. 2017, Sjöstedt Landén m.fl. 2015). 
Vissa ojämlikhetsaspekter är enklare att mäta än andra, exempelvis löner och inkomster, arbetstider och typer av anställningskontrakt. Makt och kontroll kan vara svårare att utforska. Vi har därför valt att tillämpa en enkel kategorisering av jobbens kvalitet som bygger på anställningsform och/eller arbetstider.

En första grov åtskillnad gör vi mellan tillsvidareanställning (fast jobb) och tidsbegränsad anställning (anställning på viss tid). En tillsvidareanställning på heltid betraktas i Sverige som normen för anställningar och kallas i internationell litteratur "standardkontraktsanställning". Visstids- och deltidsanställningar kan kallas "icke-standardiserade anställningar". Inom kategorin visstid ryms långvariga projektanställningar, vikariat och provanställningar inför en fast anställning. De kan vara på heltid och ha liknande drag som fasta anställningar, även om de generellt sett inte har samma anställningstrygghet. Det är viktigt att kunna skilja dem från mer otrygga visstidsanställningar, såsom korta timanställningar där de anställda kallas in vid behov per telefon eller sms och inte vet om, när eller hur mycket de kommer att få arbeta.

Om vi kombinerar anställningsformen med arbetstider får vi ytterligare en dimension av arbetets kvalitet. En fast anställning kan vara på deltid men omfatta 30-35 timmar per vecka enligt ett fast schema. Men den kan också omfatta 1-19 timmar per vecka och kräva att man är tillgänglig för att ta extra timmar för att kunna försörja sig. Sådana anställningar påminner till sin karaktär om visstidsanställningar där man kallas vid behov.

De som har fasta heltidsanställningar kan betraktas som kärnarbetskraft och har den tryggaste formen av anställning. Fasta deltidsanställningar med mycket arbetstid kan ha liknande karaktär men ger vanligen inte lika mycket inflytande som heltidsanställningarna. Inom andra branscher har dessa anställningsformer ofta kodats med könsbaserade och rasistiska stereotyper och därmed bidragit till att cementera informella hierarkier i arbetslivet (se bland annat Sohl, kapitel 3; Sjöstedt Landén m.fl. 2015; Thörnquist 2013). Visstidsanställningar som vikariat och provanställningar ger vanligen mindre inflytande, och mest utsatta är visstidsanställda som kallas vid behov. Till detta kommer att arbetsplatser kan ha inhyrd arbetskraft från bemanningsföretag eller 
i vissa fall egenföretagare. Dessutom förekommer praktikanter och subventionerade anställningar.

Hur arbetsorganisationen är uppbyggd med avseende på anställningskontrakt skiljer sig åt mellan olika branscher, men även inom branscher och inom företag i samma koncern.

\section{Polarisering av anställningskontrakt i detaljhandeln 1990-2015}

Mellan 1990 och 2015 minskade antalet fasta anställningar på hela arbetsmarknaden med 3 procent medan antalet visstidsanställningar ökade med 67 procent. I detaljhandeln var utvecklingen än mer extrem. Där minskade antalet fasta anställningar med 12 procent medan antalet visstidsanställningar mer än fördubblades.

När vi analyserar detaljhandeln utifrån SCB:s socioekonomiska indelning i arbetar- och tjänstemannayrken ser vi en tydlig polarisering av anställningskontrakten. Bland arbetare ökade antalet visstidsanställningar med hela 152 procent, bland tjänstemän minskade det med drygt 25 procent.

Men tidsbegränsad anställning är inte det enda kriteriet för ojämlika anställningskontrakt. Lägger vi till deltidsarbetet får vi ett liknande mönster. Av tabell 2.1 framgår att deltidskontrakten ökade från 53 procent till 64 procent för arbetaryrken och minskade från 40 till 21 procent för tjänstemannayrken. Genom att kombinera tidsbegränsad

Tabell 2.1. Icke-standardiserade anställningskontrakt i detaljhandelsyrken 19902015 (procent).

\begin{tabular}{llcc}
\hline & & 1990 & 2015 \\
\hline Tidsbegränsade kontrakt & Arbetare & 12 & 28 \\
& Tjänstemän & 10 & 9 \\
Deltidskontrakt & Arbetare & 53 & 64 \\
& Tjänstemän & 40 & 21 \\
Icke-standardkontrakt & Arbetare & 57 & 69 \\
& Tjänstemän & 42 & 26 \\
\hline
\end{tabular}

Källa: SCB 2015. 


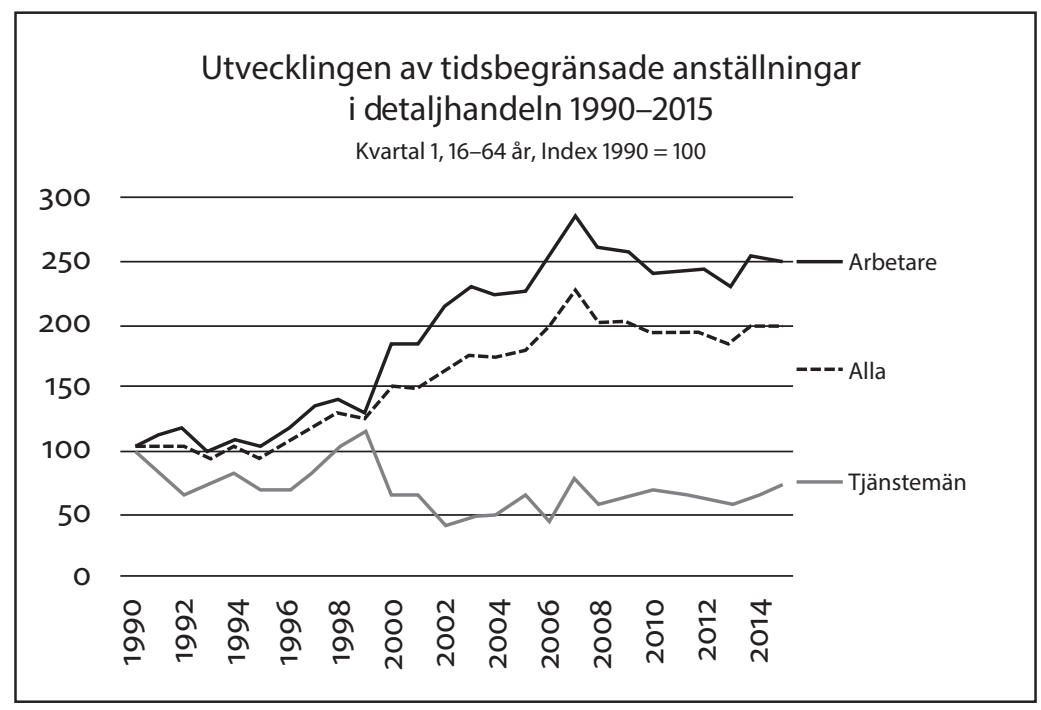

Figur 2.2. Källa: SCB 2015.

anställning med deltid får vi ett annat kriterium för icke-standardiserade anställningskontrakt. Dessa ökade från 57 till 69 procent för arbetaryrken, men minskade från 42 till 26 procent för tjänstemannayrken inom detaljhandeln.

Det är allmänt känt att kvinnodominerade sektorer har större andel osäkra anställningar. Av tabell 2.2 framgår det att kvinnor hade en större andel icke-standardkontrakt och deltidskontrakt genom hela perioden.

Tabell 2.2. Tidsbegränsade, deltids- och icke-standardkontrakt i arbetaryrken inom detaljhandeln 1990-2015. Män och kvinnor (i procent).

\begin{tabular}{llcl}
\hline & & 1990 & 2015 \\
\hline Tidsbegränsade kontrakt & Arbetare & 10 & 30 \\
& Tjänstemän & 14 & 28 \\
Deltidskontrakt & Arbetare & 22 & 52 \\
& Tjänstemän & 65 & 70 \\
Icke-standardkontrakt & Arbetare & 27 & 59 \\
& Tjänstemän & 69 & 74 \\
\hline
\end{tabular}

Källa: SCB 2015. 
Män inom arbetaryrken i detaljhandeln fick försämrade positioner mellan 1990 och 2015: kvinnor hade redan från början en hög grad av osäkra anställningar och de ökade något, men för män mer än fördubblas de, från 27 procent till hela 59 procent.

Olika typer av tidsbegränsade kontrakt skiljer sig åt med avseende på hur trygga de kan förväntas vara. Vikariat och provanställningar är generellt mer trygga former. Det som i statistiken heter "kallas vid behov" och "timanställning" är mindre trygga.

I figur 2.3 kan vi se att det utöver en total ökning av tidsbegränsade anställningar inom arbetaryrken i detaljhandeln också skett en kraftig förskjutning i typ av anställning.

Mellan 1990 och 2015 minskade de mer trygga formerna, vikariat och provanställning, från 56 procent till 22 procent. Anställningarnas egenskaper eller villkor förändrades också på grund av förändringar i den arbetsrättsliga lagstiftningen, men det syns inte i statistiken. Innan lagen om allmän visstid infördes 2007 fanns krav på att anställningen skulle vara i minst en månad, och det fanns en gräns för maximalt fem personer i denna form på arbetsplatsen. Med allmän visstid blev det tillåtet att kalla in ett obegränsat antal personer från dag till dag utan särskild motivering eller någon annan framförhållning. Det är också viktigt att komma ihåg att statistiken över tidsbegränsade anställningar kan vara missvisande och underdriven. Det förekommer att anställda erbjuds fast deltidsanställning med 5-10 timmars arbetstid och därutöver anställs på visstidskontrakt för att få fler timmar. I statistiken räknas dessa personer som tillsvidareanställda. Sådana aspekter av jobbkvalitet behöver undersökas vidare eftersom de inte syns i den offentliga statistiken.

\section{Polarisering i inkomster för butikssäljare 1990-2015}

Intresset för polariseringstendenser i arbetslivet har ökat under senare tid. Med polarisering avses här främst processer som leder till ökad ojämlikhet i arbetslivet. Här koncentrerar vi oss på fenomenet att sysselsättningen minskar i medellönejobb medan den ökar i låglönejobb och i höglönejobb, vilket leder till ökad ojämlikhet i arbetslivet. Flera 


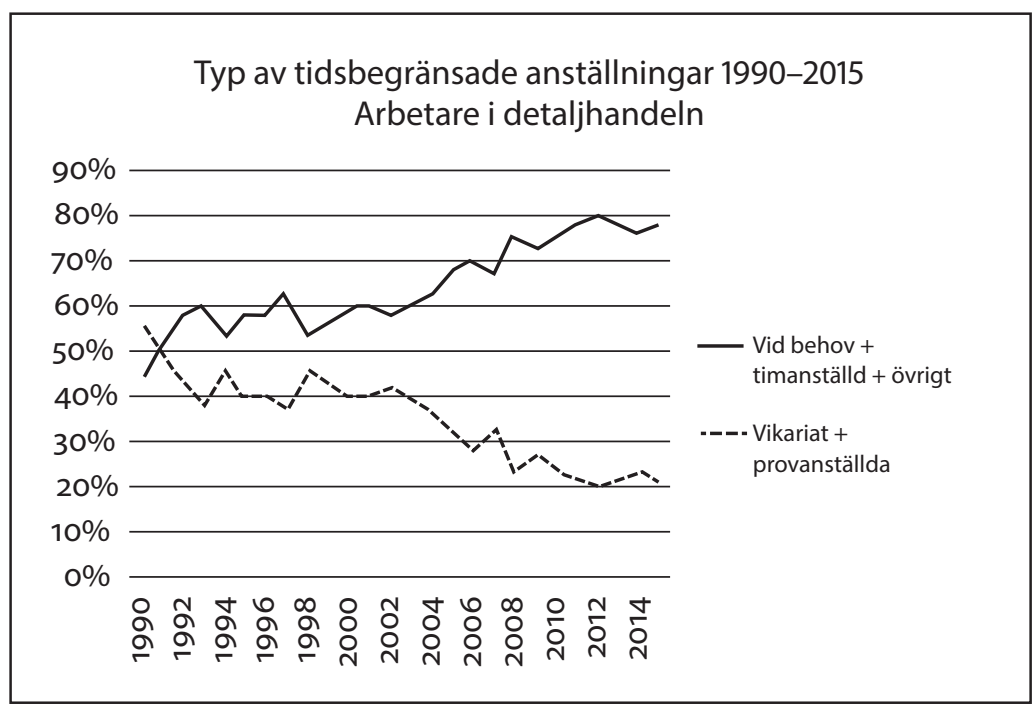

Figur 2.3. Källa: SCB 2015.

studier har visat på detta fenomen (Autor 2013; Fernández-Marcías m.fl. 2012; Goos m.fl. 2014).

Svenska forskare har visat på en allmän polariseringstrend. Rune Åberg visade utifrån registerdata i lönestrukturstatistiken att den svenska arbetsmarknaden utvecklades i polariserande riktning mellan 1997 och 2012 (Åberg 2013, 2015). Adrian Adermon och Magnus Gustavsson visade utifrån LINDA-databasen på polariseringsmönster på den svenska arbetsmarknaden mellan 1975 och 2005 (Adermon \& Gustavsson 2015).

De studier som genomförts har utgått från medianlöner. Fördelen med medianlönemåttet är att det är enhetligt och möjliggör jämförelser. Nackdelen är att lönen bara är ett av flera mått på ojämlikhet (se t.ex. Behtoui m.fl. 2017). Utöver övergripande statistiska studier på hela arbetsmarknaden finns därför också ett behov av att fördjupa analysen genom att mer utförligt studera enskilda branscher och yrken.

Vi presenterar i detta avsnitt uppgifter och resultat som fördjupar och utvidgar tidigare analyser av ojämlikhet i arbetslivet. Fördjupar i bemärkelsen att vi i detalj undersöker vad som hänt i en sektor och i ett dominerande yrke - butikssäljaryrket, vilket är det största kvinno- 
yrket inom privat sektor. Utvidgar såtillvida att vi utöver timlöner också undersöker andra villkor för arbetet i form av anställningsform, arbetstider samt månatliga löneinkomster.

Det material vi använder i detta avsnitt är individdata som arbetsmarknadens parter har samlat in och som ligger till grund för den offentliga lönestatistiken. I materialet ingår inte arbetsplatser där det saknas kollektivavtal, och det kan tänkas att det på just dessa arbetsplatser finns tydliga polariseringsmönster. Dock är täckningsgraden för kollektivavtalen så pass hög att de sannolikt påverkar även de få arbetsplatser som saknar avtal. ${ }^{3}$

En närmare undersökning av hur löne- och arbetsvillkoren för butikssäljaryrket har förändrats ger några intressanta resultat. I tabell 2.3 framgår skillnaderna mellan olika sätt att beräkna timlöner. Lönen blir högre när man summerar hela områdets löner och timmar och sedan delar dem, vilket är det sätt som timlöner för arbetaryrken beräknas på i Sverige. Om man tvärtom räknar ut lönen för varje individ och sedan tar ett medelvärde innebär det att varje individ får samma vikt oberoende av hur många timmar hen har arbetat. Eftersom de som arbetar flest timmar vanligen har högre timlön blir lönen något lägre med denna beräkningsmetod.

I en första överblick kan vi konstatera att lönespridningen minskade bland butiksförsäljarna: 199o hade de 10 procenten med högst lön 40 procent mer än de 10 procenten med lägst lön, men 2015 endast 30 procent mer. Det kan uttryckas som att 90/10-kvoten minskade från nästan 1,40 till 1,30. Om vi bara ser till timlöner finner vi alltså inga polariseringstendenser inom yrket butikssäljare.

Tabell 2.3. Butikssäljare i detaljhandeln, timlöner och spridning.

\begin{tabular}{lll}
\hline & 1990 & 2015 \\
\hline Timlöner, summa lön/summa arbetad tid & 59,29 & 139,46 \\
Timlöner, medel & 57,86 & 136,52 \\
Timlöner, median & 57,52 & 134,58 \\
Spridning 90/10 & 1,396 & 1,300 \\
\hline
\end{tabular}

Källa: Partsgemensam lönestatistik och egna beräkningar. 
Men det har också skett en förändring i typerna av anställningskontrakt, med en ökning av tillfälliga jobb och deltidsjobb. För att kunna fånga detta behöver vi titta på hur löneinkomsterna per månad utvecklades.

Tabell 2.4. Butikssäljare i detaljhandeln, månatliga löneinkomster och spridning.

\begin{tabular}{lll}
\hline & 1990 & 2015 \\
\hline Månatliga löneinkomster, median & 7436 & 15975 \\
Månatliga löneinkomster, medel & 7918 & 17735 \\
Spridning 90/10 & 5,189 & 9,55 \\
\hline
\end{tabular}

Källa: Partsgemensam lönestatistik och egna beräkningar.

Spridningen i månatlig löneinkomst ökade kraftigt. År 1990 hade de 10 procenten med högst lön 5 gånger så hög månatlig löneinkomst som de 10 procenten med lägst lön, och 25 år senare hade nästan 10 gånger så hög inkomst. Det är en mycket stor förändring.

Om vi delar in individerna i 1990 års statistik i fem lika stora grupper (kvintiler) efter månadsinkomst och analyserar förändringen av andelen individer $2015 \mathrm{ser}$ vi att antalet individer ökade i de yttersta kvintilerna (1 och 5) och minskade i mellankvintilerna. Det är ett tydligt polariserande mönster.

Det visar sig vara viktigt att skilja mellan timlön och månatlig löneinkomst om man vill analysera utvecklingen av ojämlikhet $\mathrm{i}$ branscher som har en hög grad av flexibel bemanning. Den centrala lönebildningen har under perioden huvudsakligen avtalats så att löneökningarna årligen höjts med fasta kronor och inte i procent på avtalsområdet detaljhandel. Samtidigt har minimilönerna oftast höjts med minst samma belopp som de allmänna löneökningarna under perioden. De år som de har höjts med lägre belopp har höjningen procentuellt varit lika stor som de allmänna löneökningarna. Dessa båda faktorer minskade lönespridningen, och skulle ha kunnat fungera som en motkraft mot polariseringen.

Men under perioden ökade de osäkra anställningskontrakten kraftigt. När vi tar det i beaktande ser vi en tendens till ökande ojämlikhet. Det visar att timlöneanalyser måste kompletteras med löneinkomstanalyser för att kartlägga ojämlikhet. 


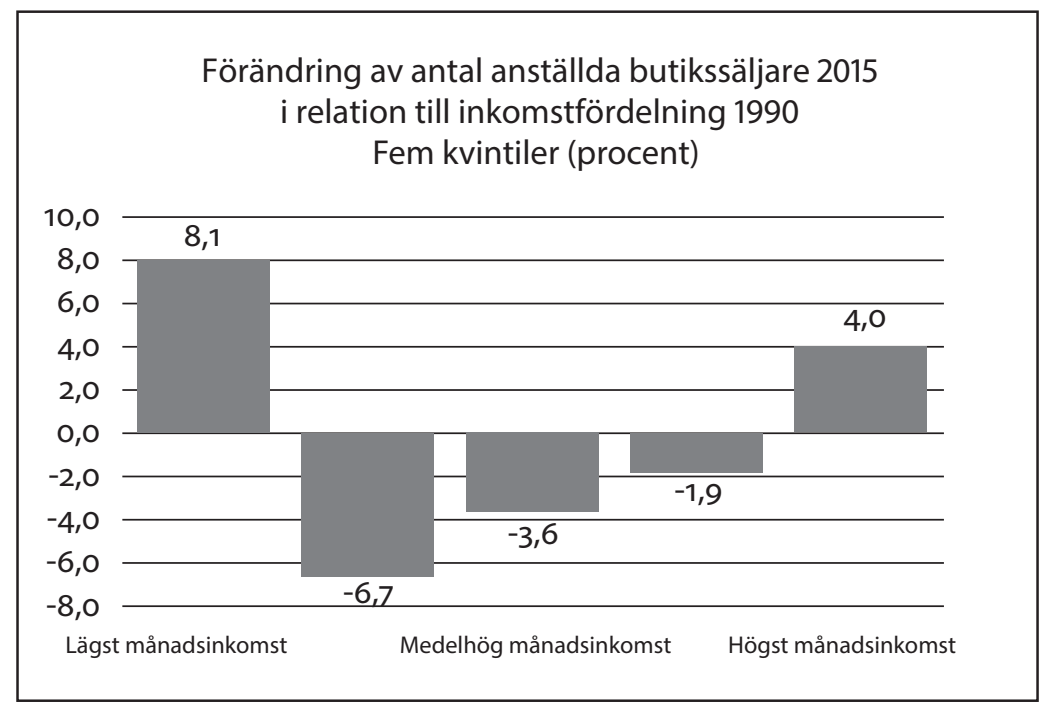

Figur 2.4. Källa: Partsgemensam lönestatistik och egna beräkningar.

\section{Klass, kön och födelseland}

Den ojämlikhet på arbetsmarknaden som tillfälliga och osäkra anställningar ger upphov till förstärks av att den drabbar grupper som utsätts för olika former av strukturell ojämlikhet. Vi vill därför granska de tidsbegränsade anställningarna och deras effekter ur ett intersektionellt perspektiv och koppla dem till de anställdas o(jäm)lika ställning - inte bara på arbetsmarknaden som helhet utan också nedbrutet på branscher och arbetsplatser.

På aggregerad nivå - hela arbetsmarknaden - är tidsbegränsade anställningar tydligt kopplade till socioekonomisk position, kön och födelseland. Osäkra anställningar är vanligare bland arbetare än bland tjänstemän, bland utrikes födda än bland inrikes födda, bland kvinnor än bland män och bland unga än bland äldre (Sohl, kapitel 3; Neergaard 2018; SCB 2015; Thörnquist 2013; Vedin 2015).

Det finns inga studier som har tittat närmare på tidsbegränsade anställningar ur ett intersektionellt perspektiv inom detaljhandeln. En orsak är att det är svårt att bryta ner data om anställningsform på branschnivå och social nivå. Med en så begränsad urvalspopulation är 


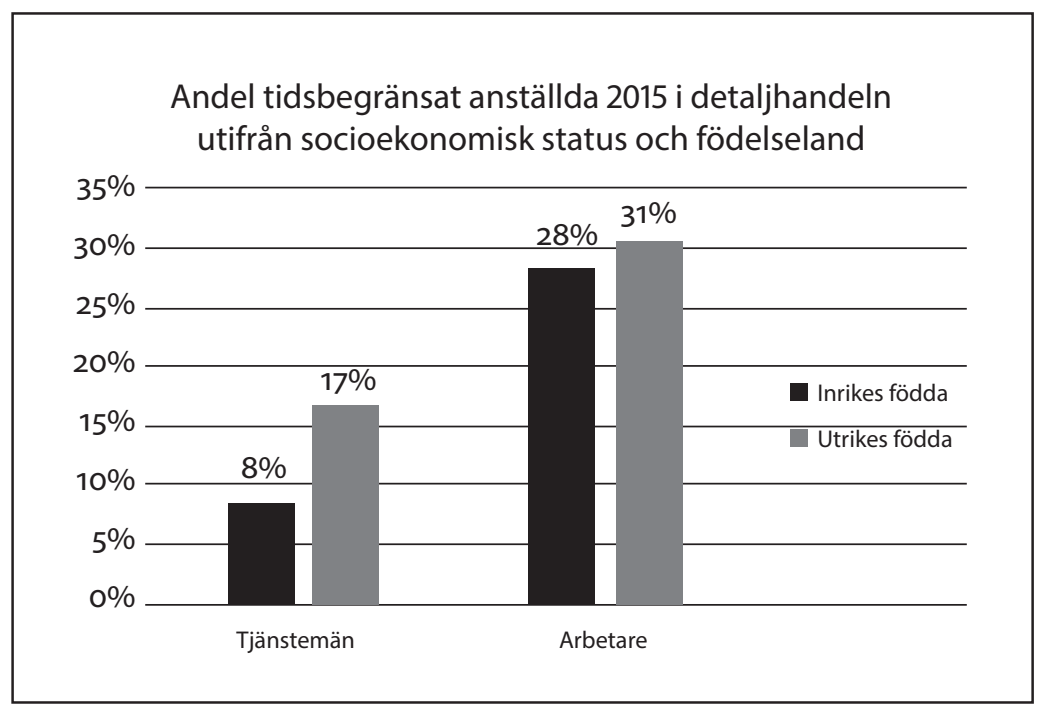

Figur 2.5. Källa: SCB 2018.

det svårare att få statistiskt säkra data på branschnivå som också ska täcka delbranscher, med avseende på klass, kön, födelseland och ålder. Den enda källa som finns i Sverige om tidsbegränsade anställningar är AKU (Arbetskraftsundersökningar). Med hjälp av särskilt beställd statistik är det dock möjligt att analysera med hänsyn till socioekonomisk bakgrund och födelseland samt kön och födelseland.

Andelen tidsbegränsade anställningar bland tjänstemän är generellt låg. Men tidsbegränsade anställningar är mer än dubbelt så vanliga bland utrikes födda tjänstemän (17 procent) som bland inrikes födda tjänstemän (8 procent). För arbetare är andelen tidsbegränsade anställningar totalt sett större, däremot är skillnaden mellan inrikes födda (28 procent) och utrikes födda (31 procent) inte särskilt stor. En tänkbar förklaring kan vara att andelen tidsbegränsade anställningar totalt sett är hög för arbetare och att det kan finnas en gräns för hur många tidsbegränsat anställda en arbetsplats kan ha innan den slutar fungera.

Att instabila anställningar är vanligare bland arbetare har att göra med deras underordnade position i arbetsorganisationen och i samhället. Skillnaden mellan utrikesfödda och inrikesfödda bland tjänstemän 


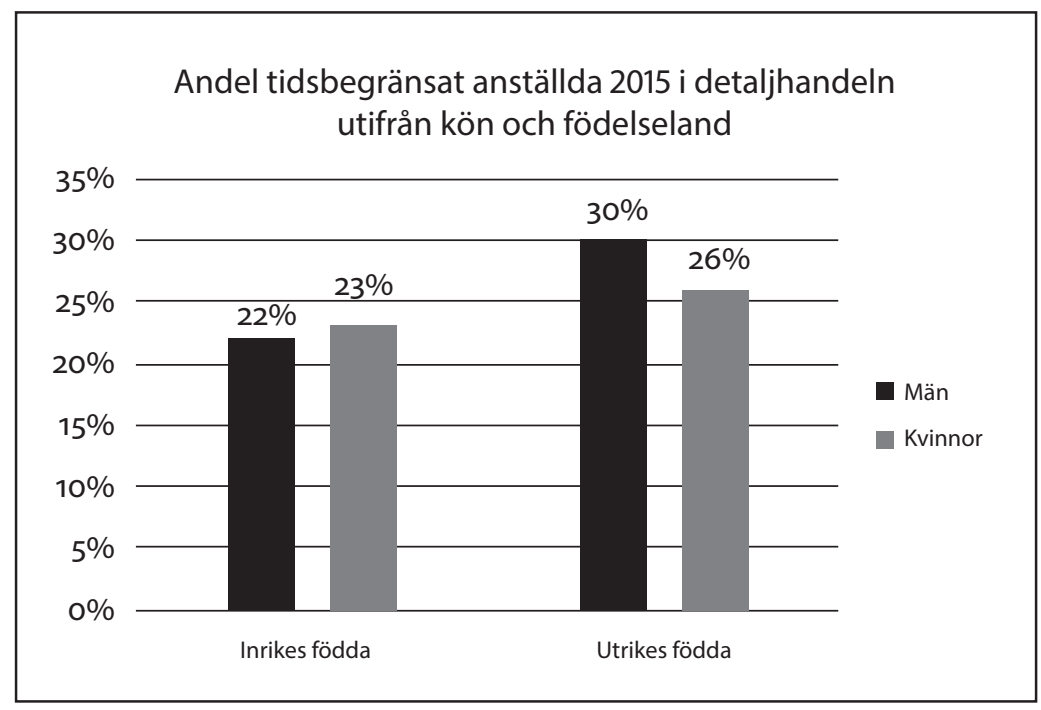

Figur 2.6. Källa: SCB 2018.

indikerar också att det finns högre trösklar för att utrikesfödda ska få en fast anställning inom tjänstemannayrken. Det tål att påpekas att vi saknar uppgifter om de anställdas ålder och vilka som är barn till migranter (ibland felaktigt och problematiskt kallade "andra generationen"), uppgifter som skulle kunna fördjupa analysen av ojämlikheten inom detaljhandeln.

Om vi ser till kön och födelseland framträder ett annat mönster. Bland utrikes födda är andelen tidsbegränsat anställda högre än bland inrikes födda, och bland utrikesfödda män är andelen än större än bland utrikesfödda kvinnor. Det återstår att förklara varför utrikesfödda kvinnor har fast anställning i högre utsträckning än utrikesfödda män.

Det saknas idag mer detaljerade branschspecifika undersökningar om hur såväl utrikesfödda som inrikesfödda med utländsk bakgrund fördelas i olika tidsbegränsade anställningar. En studie om övergångar från tidsbegränsad anställning på den svenska arbetsmarknaden som helhet visade dock att av personer som vid en viss tidpunkt hade en tidsbegränsad anställning hade endast 38 procent fått en fast anställning två år senare. Störst chans till fast anställning hade de som hade 
haft någon av de tryggare tidsbegränsade anställningsformerna, vikariat eller provanställning. För utrikes födda var risken att åter hamna i arbetslöshet eller helt hamna utanför arbetskraften högre än för inrikes födda. Chansen att övergå till ett fast jobb var också något lägre (Berglund m.fl. 2017).

Att utrikes födda generellt sett har en mer utsatt position på arbetsmarknaden är inget nytt. Men vi vet att det är en heterogen grupp och att faktorer som födelseland, kön, socialt nätverk, utbildningsbakgrund, vistelsetid och arbetslivserfarenhet påverkar möjligheterna att få ett arbete. Det finns omfattande studier som utifrån olika perspektiv och med skilda metoder visar att diskriminering förekommer i rekryteringsprocesser och även i Arbetsförmedlingens hantering av utrikesfödda (Arai m.fl. 2016; Larsson 2015).

Från politiskt håll har begreppet "utanförskap" använts för att beskriva den ojämlikhet som finns mellan dem som har ett arbete och dem som inte har det. Vår undersökning indikerar dock att ojämlikhet inte bara skapas av exkludering och utestängning utan av en organisatorisk logik som skapar sårbara villkor för en växande andel av arbetskraften.

\section{Konsekvenser för arbetsmiljön och de anställdas hälsa}

Personer som har visstidsanställningar är i en mer utsatt position än dem som har fasta anställningar. De kan ha svårt att få lån, kunna skaffa egen bostad eller planera sin tillvaro. Men det finns också en särskild utsatthet på arbetsplatsen. Det finns en ständig press att vara tillgänglig och att kunna ställa upp på kort varsel. Annars riskerar man att inte längre bli erbjuden extra timmar. Beroendeställningen till arbetsgivaren medför att det kan vara svårt att säga ifrån vid till exempel sexuella trakasserier. Att visstidsanställda upplever större otrygghet i sitt liv och har en sämre arbetssituation än fast anställda är väl belagt i forskningen (Aronsson m.fl. 2000; Waenerlund m.fl. 2011; Waenerlund 2013).

En fråga som inte fått lika stor uppmärksamhet är hur valet av arbetsorganisation påverkar hela arbetsplatsen. Är arbetsmiljön sämre på arbetsplatser som i större utsträckning använder sig av flexibel bemanning? Kan det vara så att graden av anställningstrygghet smittar av sig och påverkar hela arbetsplatsen? Det finns studier som tyder på 
att anställningsotrygghet påverkar även dem som har en trygg anställning (Låstad 2015).

För detaljhandeln finns inte någon statistik över detta. Men vi har tagit del av två större enkätundersökningar rörande medlemmar respektive skyddsombud i Handels som tyder på att valet av arbetsorganisation påverkar arbetsklimatet på hela arbetsplatsen. ${ }^{4}$ Den första undersökningen utfördes 2012. En slumpmässigt rekryterad panel av medlemmar i Handelsanställdas förbund fick frågan "Hur vanligt är det att kollegorna på din arbetsplats har en tidsbegränsad/tillfällig anställning?" Svarsalternativen gavs i en fyrgradig skala (väldigt vanligt, ganska vanligt, ganska ovanligt, väldigt ovanligt) plus ett vet ej-alternativ. Utöver detta ställdes traditionella frågor om arbetsmiljön och arbetsklimatet på arbetsplatsen, exempelvis om man upplevde att det fattades personal, om man kom hem utmattad, om man upplevde stress, med mera. Här gavs svarsalternativen i en femgradig skala (alltid, ofta, ibland, sällan, aldrig) plus ett vet ej-alternativ.

Genom att kombinera svaren om hur vanligt det var med tillfälliga anställningar på arbetsplatsen med svaren om arbetsmiljö går det att få en bild av hur valet av arbetsorganisation kan påverka arbetsklimatet. För att göra det än tydligare väljer vi att endast använda svaren från fast anställda. 
Tabell 2.5. Andel fast anställda som svarade "alltid" eller "ofta", efter förekomst av visstidsanställda på arbetsplatsen (procent).

\begin{tabular}{lcc}
\hline & $\begin{array}{l}\text { Låg grad av visstids- } \\
\text { anställningar }\end{array}$ & $\begin{array}{l}\text { Hög grad av visstids- } \\
\text { anställningar }\end{array}$ \\
\hline $\begin{array}{l}\text { Upplever du att det fattas personal på } \\
\text { din arbetsplats? }\end{array}$ & 35 & 65 \\
$\begin{array}{l}\text { Upplever du stress på grund av dålig } \\
\text { arbetsledning? }\end{array}$ & 32 & 58 \\
$\begin{array}{l}\text { Upplever du att du kommer hem ut- } \\
\text { mattad från arbetet? }\end{array}$ & 36 & 58 \\
$\begin{array}{l}\text { Upplever du extra ansvar för ny eller } \\
\text { tillfällig personal? }\end{array}$ & 29 & 52 \\
$\begin{array}{l}\text { Upplever du ansvar för att lära upp ny } \\
\text { eller tillfällig personal? }\end{array}$ & 15 & 35 \\
$\begin{array}{l}\text { Upplever du stress på grund av schema- } \\
\text { läggning och brist på planering? }\end{array}$ & 19 & 37 \\
$\begin{array}{l}\text { Upplever du konkurrens om timmar på } \\
\text { arbetsplatsen? }\end{array}$ & 36 & 70 \\
\hline
\end{tabular}

Källa: Handels/Novus medlemsundersökning om arbetsmiljö 2012.

Även om detta är självskattningar i en enkät så framträder ett tydligt mönster. På arbetsplatser med många visstidsanställda upplevde fler fast anställda arbetsmiljörelaterade problem: personalbrist, stress på grund av dålig arbetsledning och planering, att komma hem utmattad efter jobbet och att få ta extra ansvar för att lära upp ny eller tillfällig personal.

Den andra enkätundersökningen som Handels genomförde riktades till skyddsombud på arbetsplatserna. En fördel är att skyddsombud är specialister på arbetsmiljöfrågor. En nackdel är att undersökningen blir begränsad till arbetsplatser där det finns skyddsombud - som sannolikt är bättre arbetsplatser. Vi kan förvänta oss att resultatet är mer positivt än om arbetsplatser utan skyddsombud hade funnits med, men vårt syfte är att se om det finns skillnader mellan arbetsplatser med stor och liten förekomst av visstidsanställningar.

Till skyddsombuden ställdes frågan "I hur hög utsträckning förekommer det visstidsanställda?" De fick sex svarsalternativ (förekommer inte alls, förekommer i låg utsträckning, förekommer i viss utsträckning, förekommer i ganska hög utsträckning och förekommer i hög 
Tabell 2.6. Andel skyddsombud som svarade "förekommer i ganska hög utsträckning" eller "förekommer i hög utsträckning", efter förekomst av visstidsanställda på arbetsplatsen (procent).

\begin{tabular}{|c|c|c|c|}
\hline & $\begin{array}{l}\text { Arbetsplatser } \\
\text { med låg grad av } \\
\text { visstidsanställ- } \\
\text { ningar }\end{array}$ & $\begin{array}{l}\text { Arbetsplatser } \\
\text { med viss grad av } \\
\text { visstidsanställ- } \\
\text { ningar }\end{array}$ & $\begin{array}{l}\text { Arbetsplatser } \\
\text { med hög grad av } \\
\text { visstidsanställ- } \\
\text { ningar }\end{array}$ \\
\hline $\begin{array}{l}\text { Förekommer sjukskrivning på } \\
\text { grund av stressrelaterad ohälsa? }\end{array}$ & 15 & 29 & 45 \\
\hline $\begin{array}{l}\text { Förekommer konkurrens om tim- } \\
\text { mar mellan anställda? }\end{array}$ & 10 & 23 & 41 \\
\hline $\begin{array}{l}\text { Förekommer brist på bemanning/ } \\
\text { personal? }\end{array}$ & 20 & 42 & 50 \\
\hline $\begin{array}{l}\text { Förekommer att personal kallas in } \\
\text { efter behov? }\end{array}$ & 31 & 51 & 71 \\
\hline $\begin{array}{l}\text { Förekommer jobberbjudanden } \\
\text { med sms och kort svarstid? }\end{array}$ & 11 & 20 & 42 \\
\hline $\begin{array}{l}\text { Förekommer missnöje bland } \\
\text { anställda för att de inte făr fler } \\
\text { timmar? }\end{array}$ & 20 & 38 & 51 \\
\hline $\begin{array}{l}\text { Förekommer nyanställning trots } \\
\text { att det finns personal som vill ha } \\
\text { mer tid? }\end{array}$ & 18 & 33 & 57 \\
\hline $\begin{array}{l}\text { Förekommer det att deltidsanställ- } \\
\text { da arbetar mertid? }\end{array}$ & 33 & 42 & 71 \\
\hline $\begin{array}{l}\text { Förekommer att relationen mellan } \\
\text { personal och chefer är dålig/myck- } \\
\text { et dålig? }\end{array}$ & 14 & 22 & 26 \\
\hline
\end{tabular}

Källa: Handels skyddsombudsenkät 2015.

utsträckning) plus ett vet ej-alternativ. I vår redovisning av resultaten har vi slagit ihop svarsalternativen "förekommer inte alls" och "förekommer i låg utsträckning" till "låg grad av visstid"; svarsalternativet "förekommer i viss utsträckning" motsvarar "viss grad av visstid"; och "förekommer i ganska hög utsträckning" och "förekommer i hög utsträckning" motsvarar "hög grad av visstid". De arbetsmiljörelaterade frågorna hade samma sex svarsalternativ.

En närmare analys av resultaten av skyddsombudsenkäten visade i princip samma mönster som i undersökningen av fast anställda. I samtliga frågor visade det sig att skyddsombud på arbetsplatser med 
hög grad av visstidsanställningar upplevde större arbetsmiljörelaterade problem. Sjukskrivningar på grund av stressrelaterad ohälsa var tre gånger så vanligt. Det var vanligare att det rådde brist på personal, att anställda konkurrerade om timmar, att anställda kallades in med sms med kort varsel, att deltidsanställda fick arbeta mer än vad som angavs i kontraktet samt att anställda var missnöjda. Även relationen mellan personal och chefer upplevdes sämre.

\section{Avslutande diskussion}

Den internationella ekonomiska samarbetsorganisationen OECD har under senare år alltmer intresserat sig för ojämlikhet och dess effekter för samhällsekonomin. Forskare knutna till organisationen har i studier framhållit att den ökande ojämlikheten inte bara är ett socialt problem i sig utan också något som hämmar den ekonomiska utvecklingen. En viktig faktor bakom den ökande ojämlikheten är enligt OECD den kraftiga expansionen av tillfälliga och osäkra anställningar. Trots tider av ökande sysselsättning, som normalt brukar leda till minskade klyftor, ökade ojämlikheten i flertalet länder. En orsak är att en stor del av de nya anställningarna är osäkra och icke-standardiserade visstids- och deltidsanställningar. Det har bidragit till att ojämlikheten i inkomster ökat trots ökad sysselsättning. Enligt OECD måste politiken fokusera på att öka både kvantiteten och kvaliteten på jobben. Osäkra anställningar skapar fattigdom och för alltför många anställda är de inte några språngbrädor till en fastare etablering på arbetsmarknaden utan snarare fällor som ger en osäker tillvaro, låga inkomster, sämre möjligheter till utbildning och kompetensutveckling - sådant som hämmar framtida ekonomisk tillväxt (OECD 2015).

När OECD tar upp ojämlikhet som ett socialt problem med tillväxthämmande effekter kan det tolkas som en öppning för nya fördelningspolitiska förhandlingar och konsensuslösningar mellan parterna. Men om vi vill belysa prekaritetens maktdimensioner behöver vi också analysera hur osäkra anställningar är kopplade till andra former av strukturell ojämlikhet.

De flesta studier om tillfälliga och osäkra anställningar har ett makroperspektiv på arbetsmarknaden. Men det finns skillnader mel- 
lan olika sociala grupper och inte minst mellan olika branscher. Vår undersökning om detaljhandeln understryker detta.

Under perioden 1990-2015 ökade de tidsbegränsade anställningarna med 67 procent på arbetsmarknaden som helhet. I detaljhandeln var ökningen 102 procent. En närmare analys av detaljhandeln visar att utvecklingen inte var jämn. Bland arbetare ökade de tidsbegränsade anställningarna med hela 152 procent, bland tjänstemännen minskade de med drygt 25 procent. Samma mönster ser vi när vi kombinerar tidsbegränsade anställningar med deltidsanställningar: bland arbetare ökade dessa anställningar kraftigt, bland tjänstemän minskade de. Kvinnor hade under hela perioden en betydligt större andel icke-standardiserade anställningskontrakt än män. Däremot var ökningen större bland arbetarmän än bland arbetarkvinnor under perioden.

När vi ser till olika typer av tidsbegränsade anställningar ser vi att de som anses vara tryggare former - vikariat och provanställningar minskade medan behovs- och timanställningar ökade. Innehållet i de sistnämnda försvagades genom införandet av allmän visstid 2007, då det inte längre krävdes objektiva skäl, minst en månads kontrakt och begränsning till maximalt fem sådana anställningar per arbetsplats.

Vår undersökning av inkomstfördelningen inom det dominerande yrket butikssäljare visade att analyser som utgår från endast lönefördelning kan bli grovt missvisande. När vi tittade på timlönernas utveckling 1990-2015 såg inkomstspridningen ut att ha minskat. Men när vi tog hänsyn till de timmar som fanns på anställningskontraktet och undersökte den faktiska månatliga löneinkomsten så fann vi att inkomstspridningen nästan hade fördubblats inom detta yrke. Resultatet ger stöd åt OECD:s slutsats att förekomsten av olika anställningskontrakt (tidsbegränsade kontrakt och deltidskontrakt) är en viktig faktor för att förklara den ökande ojämlikheten på arbetsplatserna.

Det är från såväl svensk som internationell litteratur känt att tillfälliga och osäkra anställningar är ojämnt fördelade utifrån klass, kön och födelseland. I detaljhandeln återkommer detta mönster. Utrikes födda har i högre grad tidsbegränsade anställningar än inrikes födda - det gäller för såväl tjänstemannayrken som arbetaryrken inom detaljhandeln. Vårt material har inte medgett någon djupare analys av detta. För framtida studier vore det önskvärt att få fram mer detaljerade individdata för att 
kunna studera ojämlikhetens utveckling inom olika branscher och olika sociala grupper. Dessvärre saknas det dataunderlag för de systematiska intersektionella analyser som nationell och internationell forskning efterlyser (se t.ex. Thörnquist \& Engstrand 2011; Kalleberg \& Vallas 2017).

Vi ställde oss frågan om osäkra anställningar påverkade klimatet på hela arbetsplatsen. Kan graden av anställningstrygghet smitta av sig på en hel arbetsplats? Mycket tyder på det. Vi har utgått från två enkätstudier som Handels genomförde bland sina medlemmar. De byggde visserligen på självskattning, men visade ett tydligt mönster: på arbetsplatser med hög andel visstidsanställda var den psykosociala arbetsmiljön betydligt sämre - bland annat förekom fler sjukskrivningar till följd av stressrelaterad ohälsa, högre konkurrens mellan anställda om timmar, sämre relationer mellan anställda och chefer och högre upplevd grad av personalbrist. Vi efterlyser mer forskning om hur valet av arbetsorganisation - utifrån val av olika flexibilitetsstrategier - påverkar hälsan hos olika sociala grupper av anställda.

På ett makroplan handlar den ökande ojämlikheten om att en rubbad maktbalans mellan arbete och kapital har försvagat de anställdas positioner på arbetsmarknaden. Men orsakerna till denna rubbade maktbalans är komplicerade. I internationell litteratur brukar man lyfta fram 1970-talets ekonomiska kriser och den tilltagande finansialiseringen med en ny företags- och ägarstyrning som en startpunkt för expansionen av mer osäkra anställningar. Med finansialiseringen av ekonomin flyttade företagens fokus från att göra långsiktiga investeringar i produktionen till att bejaka finansmarknadernas behov av mer kortsiktiga finansiella vinster. Fokus på aktieägarnas intressen (share holder values) ledde till ökad kortsiktighet och ökad benägenhet att dra ner på kostnader för att driva fram högre avkastning. Med outsourcing, offshoring och mer slimmade arbetsorganisationer kunde kostnaderna hållas nere. Mer flexibla och osäkra anställningsformer är ett annat sätt att slimma arbetsorganisationen och därmed hålla ner kostnaderna. Det är också vanligt att tillskriva utvecklingen en försvagad fackföreningsrörelse och därav ökande problem med att ta till vara löntagarnas intressen. Denna försvagning kan i sin tur bero på den ökade arbetslöshet som finansialiseringen har medfört samt på slimmade organisationer med alltmer osäkra anställningar (Kalleberg \& Vallas 2017). 
I Sverige inträffade expansionen av tillfälliga anställningar senare än i flertalet västländer - under 1990-talet snarare än 1970-talet. Den underliggande orsaken för svensk del var den kraftiga ökning av arbetslösheten som 1990-talskrisen utlöste. På liknande sätt som 1970-talets kriser i andra delar av västvärlden rubbade 1990-talskrisens höga arbetslöshet maktbalansen mellan arbete och kapital. Ett uttryck för detta var de institutionella förändringar som inträffade under perioden. Anställningsskyddslagstiftningen ändrades några gånger och trenden var att underlätta alltmer för företagen att anställa på viss tid, på bekostnad av de anställdas trygghet. Ett vanligt argument för att underlätta visstidsanställningar är att de skulle vara ett sätt att öka sysselsättningen. Även om det är svårt att vetenskapligt visa att så skulle vara fallet kan sådana argument ljuda starkare när det råder hög arbetslöshet och det inte finns något tillräckligt starkt organiserat motstånd. Först ökar arbetslösheten och därefter kommer förslag för att försvaga anställningsskyddet. Dessa båda faktorer samverkar och bidrar till ökningen av tidsbegränsade anställningar, dock i olika utsträckning för olika grupper av anställda. Ur ett längre tidsperspektiv finns det därför anledning att problematisera kontinuiteten mellan arbetsmarknadens etniska och könsmässiga differentiering och framväxten av ett splittrat och försvagat arbetarkollektiv.

\section{Noter}

1 Full sysselsättning är här ett relativt begrepp, merparten av de förvärvsarbetande inrikes födda kvinnorna arbetade deltid. Invandrade kvinnor hade inte bara en högre förvärvsfrekvens än inrikes födda utan arbetade dessutom oftare heltid.

2 För att fånga denna utveckling använder vi oss av kvartalsdata för första kvartalet varje år. Genom att använda första kvartalet får vi dels en naturlig säsongrensning, dels ett kvartal med så få tillfälliga säsongsanställningar som möjligt.

3 I underlaget för år 1990 och 2015 utgår vi från det dominerande kollektivavtalet för detaljhandel på arbetarsidan, som omfattade 66866 personer 1990 och 113352 personer 2015. För att kunna jämföra utvecklingen inom ett yrke behöver vi förhålla oss till förändringar i yrkeskoderna: 1990 användes NYK 83 och 2015 användes SSYK 2012.

4 Medlemsundersökningen 2012 är utförd av Novus på en slumpmässigt rekryterad panel av medlemmar i Handelsanställdas förbund. Inom detaljhandeln var antalet svarande 1024 individer och undersökningens resultat är viktade efter bortfallsanalys. Skyddsombudsundersökningen 2015 är en undersökning till alla skyddsombud i organisationen. Resultaten har tidigare publicerats av Handelsanställdas förbund. 


\section{Referenser}

Adermon, A. \& Gustavsson, M. (2015) "Job polarization and task-biased technological change: Evidence from Sweden, 1975-2005". Scandinavian Journal of Economics 117(3):878-917.

Arai, M., Gartell, M., Rödin M. \& Özcan, G. (2016) Arbetsförmedlares beslutsfattande och stereotyper kopplade till utseende. IFAU, Rapport 2016:17. Uppsala: IFAU.

Aronsson, G., Gustafsson, K. \& Dallner, M. (2000) Anställningsformer, arbetsmiljö och hälsa i ett centrum-periferiperspektiv. Rapportserie Arbete och hälsa 200o:9. Stockholm: Arbetslivsinstitutet.

Autor, D. (2013) "The 'task approach' to labor markets: An overview", Journal of Labour Market Research 46(3):185-199.

Behtoui, A., Boréus, K., Neergaard, A. \& Yazdanpanah, S. (2017) Att verka för jämlika arbetsplatser. En studie av jämlikhet och ojämlikhet mellan anställda $i$ äldrevården. Linköping: Linköping University Electronic Press.

Berglund, T., Håkansson, K., Isidorsson, T. \& Alfonsson, J. (2017) "Tidsbegränsat anställdas framtida arbetssituation", Arbetsmarknad \& Arbetsliv, 23(2).

Chan, A. (red.) (2011) Wal-Mart in China. Ithaca \& London: ILR Press/Cornell University Press.

Cingano, F. (2014) "Trends in income inequality and its impact on economic growth", OECD Social, Employment and Migration Working Papers, Nr 163, Paris: OECD Publishing.

Coulter, K. (2014) Revolutionizing retail: Workers, political action and social change. New York: Palgrave Macmillan.

Daunfeldt, S-O., Johansson, D. \& Seerar Westerberg, H. (2018) "Which firms provide jobs for unemployed non-Western immigrants?", HUI Working Paper Series, nr 133.

Fernández-Marcías, E., Hurley, J. \& Storrie, D. (red.) (2012) Transformation of the employment structure in the EU and USA, 1995-2007, Basingstoke: Palgrave Macmillan.

Goos, M., Manning A. \& Salomons A. (2014) "Explaining job polarization: routinebiased technological change and offshoring", American Economic Review, 104(8):2509-2526.

Handels (2015) Skyddsombudsenkät.

Handels/Novus (2012) Medlemsundersökning om arbetsmiljö.

Kalleberg, A. (2011) Good jobs, bad jobs: The rise of polarized and precarious employment systems in the United States, 1970s to 200os. New York: Russell Sage Foundation.

Kalleberg, A. \& Vallas, S. (2017) "Probing precarious work: Theory, research, and politics”, I A. Kalleberg \& S. Vallas (red.) Precarious work. Research in the sociology of work, vol. 31. Bingley: Emerald Publishing Limited.

Larsson, J.K. (2015) Integrationen och arbetets marknad: hur jämställdhet, arbete och annat "svenskt" görs av arbetsförmedlare och privata aktörer. Falun: Atlas akademi.

Lichtenstein, N. (2006) "Wal-Mart: A template for twenty-first century capitalism", I N. Lichtenstein (red.) Wal-Mart: The face of twenty-first century capitalism, New York: The New Press. 
LO (2017) Anställningsformer och arbetstider 2017. Stockholm: LO.

Låstad, L. (2015) Job insecurity climate. The nature of the construct, its associations with outcomes, and its relation to individual job insecurity. Stockholm: Stockholms universitet, Psykologiska institutionen.

Mulinari, P. \& Selberg, R. (red.) (2011) Arbete - Intersektionella perspektiv. Malmö: Gleerups.

Neergaard, A. (2018) Klassamhällets rasifiering i arbetslivet, Rapport 14 i Klass i Sverige. Stockholm: Katalys.

Neilson, B. \& Rossiter, N. (2008) "Precarity as a political concept, or, Fordism as exception", Theory Culture Society 25(7-8):51-72.

OECD (2015) In it together: Why less inequality benefits all. Paris: OECD Publishing.

SCB (2015) AKU Specialbeställd länkad statistikserie 1990-2015.

SCB (2018) AKU Sysselsättningsstatistik.

Sjöstedt Landén, A., Olofsdotter, G. \& Bolin, M. (2015) Sprickor, öppningar \& krackeleringar - nya perspektiv på arbetsmiljö. Sundsvall: Mittuniversitetet, Forum for Gender Studies.

Standing, G. (2011) The precariat: The new dangerous class. London: Bloomsbury Academic.

Thörnquist, A. (2013) Mångfaldens marknad och arbetets villkor. Om följder av kundval (LOV) i hemtjänsten. Lund: WTS, Arbetsliv i omvandling.

Thörnquist, A. \& Engstrand Å-K. (red.) (2011) Precarious employment in perspective. Old and new challenges to working conditions in Sweden. Bryssel: Peter Lang.

Ton, Z. (2014) The good jobs strategy. How the smart companies invest in employees to lower costs \& boost profits. Cambridge, Mass.: MIT Sloan School of Management.

Waenerlund, A-K. (2013) Temporary employment and illness. Umeå: Umeå universitet, Institutet för folkhälsa och klinisk medicin.

Waenerlund, A-K., Gustafsson, P., Virtanen, P. \& Hammarström, A. (2011) "Is the core-periphery labour market structure related to perceived health? Findings of the Northern Swedish Cohort”. BMC Public Health 11:956.

Waenerlund, A-K., Virtanen P. \& Hammarström A. (2011) "Is temporary employment related to health status?: Analysis of the Northern Swedish Cohort", Scandinavian Journal of Public Health 39(5):533-539.

Vedin, U. (2015) I skuggan av hög arbetslöshet - om flykting- och anhöriginvandrares arbetsmarknadsetablering, Delrapport 20: Full sysselsättning och solidarisk lönepolitik. Stockholm: LO.

Virno, P. (2011) Multitudens grammatik. Hägersten: Tankekraft.

Åberg, R. (2013) "Tjugohundratalets arbetsmarknad: fortsatt uppkvalificering eller jobbpolarisering?" Ekonomisk Debatt 6-15.

Åberg, R. (2015) Svensk arbetsmarknad och polarisering efter millennieskiftet, Umeå: Umeå universitet, Sociologiska institutionen. 